\title{
PRINSIP NORMA-NORMA BERTUTUR YANG BERETIKET DAN BERETIKA DALAM AL-QURAN
}

\author{
Shafruddin Tajuddin* \\ *Mahasiswa Program Studi Agama dan Lintas Budaya \\ Minat Studi Kajian Timur Tengah \\ Sekolah Pascasarjana Universitas Gadjah Mada \\ Email: shaftachaniago@yahoo.com \\ Promotor: \\ Prof. Dr. Syamsul Hadi, SU., MA. \\ Prof. Dr. Chamamah Soeratno \\ Prof. Dr. Soepomo Poedjosoedarmo
}

\begin{abstract}
In linguistic norms, the language of the Quran consists of words, sentences, and paragraphs which are full of meaning. Therefore, based on this aspect, it can be approximated as the other text that can be studied and researched through linguistic elements, as expressed in the form of linguistic structure, both textual and contextual. The language of the Quran is no longer just words, phrases, and sentences as a reading routines Muslims, but also as a sign and message and also information to communicate our Mankind that in the texts of the Quran contained linguistic discourse strands of substitutions. Therefore, this research is an ethnographic study of communication that is qualitative descriptive, and the problem is focused directly to the principles of spoken norms as the main observation variable or formal object, and can be formulated "How are tagged spoken norms and ethics in the Quran?". The purpose of this study was to reveal concretely about the principles the ethical norms and tagged speak contained in the Qur'an. The data contains the discourse of substitutions on the linguistic text of the Quran, searched and analyzed using the ethnographic instrument of communication. This means that this study is based on the theory of speech ethnography or the ethnography of communication with the concept of the English acronym "SPEAKING". The data from the language text of the Quran are discussed in this study showed the disclosure principles of tagged spoken norms and ethics in the Qur'an. This means that the discussion proved that the verses that speak of substitutions are principles, beliefs, attitudes, doctrines, and guidelines for how to speak with etiquette and ethical speech principles. This principle is universal for anyone and in any language. This is so that communication can take place with a good and harmonious.
\end{abstract}

Keywords: The language of the Quran, Principle, Norms of speak, Etiquette and Ethics 


\begin{abstract}
ABSTRAK
Secara norma linguistik, bahasa Al-Quran terdiri dari kata, kalimat, dan paragraph yang sarat makna. Maka dari itu, dilihat dari aspek ini, ia dapat didekati sebagaimana teks-teks lainnya yang dapat dikaji, ditelusuri dan diteliti melalui unsur-unsur linguistiknya, karena diutarakan dalam bentuk struktur kebahasaan, baik secara tekstual maupun kontekstual. Bahasa Al-Quran bukan lagi sekedar kata-kata, frasa, dan kalimat yang menjadi bacaan rutinitas umat Islam, tetapi juga sebagai tanda dan pembawa pesan dan informasi untuk dikomunikasikan kepada umat manusia bahwa di dalam teks-teks kebahasaan Al-Quran terdapat untaian wacana pertuturan mengenai norma-norma bertutur. Oleh karena itu, Penelitian ini merupakan kajian etnografi komunikasi yang bersifat kualitatif deskriptif, dan masalahnya difokuskan langsung kepada prinsip norma-norma bertutur sebagai variabel pengamatan utama atau objek formal, dan dapat dirumuskan "Bagaimana norma-norma bertutur yang beretiket dan beretika dalam Al-Quran". Tujuan penelitian ini untuk mengungkapkan secara konkret tentang prinsip norma-norma bertutur yang beretiket dan beretika atas dasar teks kebahasaan Al-Quran, Datadata yang mengandung wacana pertuturan pada teks bahasa Al-Quran, dicari dan ditelaah dengan menggunakan instrument etnografi komunikasi. Artinya penelitian ini dilandasi oleh teori etnografi wicara atau etnografi komunikasi dengan konsep akronim bahasa Inggris "SPEAKING". Data-data dari teks bahasa Al-Quran yang dibahas dalam penelitian ini menunjukkan kepada terungkapnya prinsip norma bertutur dalam Al-Quran. Artinya pembahasannya membuktikan bahwa ayat-ayat yang berbicara mengenai pertuturan adalah azas, keyakinan, sikap, ajaran, dan pedoman bagaimana cara bertutur yang beretiket dan beretika. Prinsip ini bersifat universal bagi siapa saja dan dalam bahasa apa saja. Hal ini agar komunikasi dapat berlangsung dengan baik dan harmonis.
\end{abstract}

Kata Kunci: Bahasa Al-Quran, Prinsip, Norma Bertutur, Etiket dan Etika 


\section{PENGANTAR}

Bahasa Al-Quran bukan lagi sekedar kata-kata, frasa, dan kalimat yang menjadi bacaan rutinitas umat Islam, tetapi juga sebagai tanda dan pembawa pesan dan informasi untuk dikomunikasikan kepada umat manusia.

Oleh karena itu, bahasa Al-Quran bukan sebatas proses komunikasi antara Allah dan RasulNya, antara Allah dan hambaNya, antara Rasul dan umatnya, antara sesama umat manusia, melainkan bahasa komunikasi yang di dalamnya maksud dan pesan, dan ini terdapat pada teks kebahasaannya.

Secara norma linguistik, bahasa Al-Quran terdiri dari kata, kalimat, dan paragraph yang sarat makna. Karenanya dilihat dari aspek ini, ia dapat didekati sebagaimana teks-teks lainnya yang dapat dikaji dan diteliti.

Di dalam teks kebahasan Al-Quran terdapat untaian wacana pertuturan yang dapat ditelaah dan ditelusuri melalui unsurunsur linguistik, baik secara tekstual maupun kontekstual. Sebagai contoh, surat Luqman (31) ayat 18 :

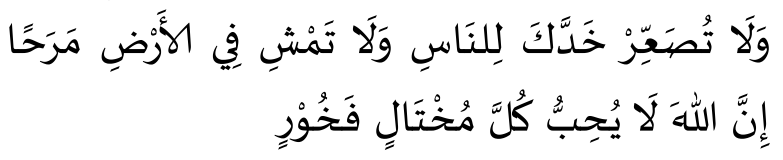

Dan janganlah kamu memalingkan mukamu dari manusia (karena sombong) dan janganlah berjalan di muka bumi ini dengan angkuh. Sungguh, Allah tidak menyukai orang orang yang sombong lagi membanggakan diri. (Q.S. Luqman (31) :18)

Ayat ini menunjukkan adanya proses pertuturan antara Allah dan hambaNya dengan bahasa larangan untuk tidak berperilaku bergaya sombong. Namun apakah informasi ayat ini hanya sebatas pemahaman dalam perilaku bergaya sombong? Kalau iya, artinya pemahamannya hanya sebatas memahami terjemahannya saja. Kalau memang demikian, Apakah cukup sekedar membaca dan memahami terjemahannya saja tanpa melihat unsur kebahasa-arabannya? Apakah ada maksud dan pesan lainnya yang dapat ditelusuri dalam konteks perilaku berbahasa sombong melalui unsur kebahasaannya? Apa yang didapat bila penelusurannya dilakukan secara perspektif sosiolinguistik dan pragmatik?

Sebagai contoh lainnya, surat Al-Isra (17) ayat 23

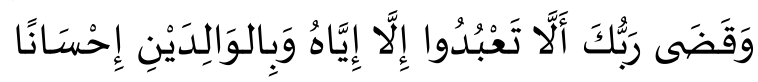

Dan Tuhanmu telah memerintahkan supaya kamu jangan menyembah selain Dia dan hendaklah kamu berbuat baik kepada ibu bapakmu. (Q.S. Al-Isra (17) : 23)

Ayat ini menunjukkan adanya larangan dan perintah Allah kepada hambaNya. Namun apakah informasi ayat ini hanya sebatas proses pertuturan dalam konteks melarang dan memerintah? Apakah teks ini hanya cukup dipahami melalui terjemahanya saja tanpa dapat ditelusuri melalui unsur kebahasa-arabannya, padahal terdapat perbedaan yang mencolok antara bahasa Indonesia dan bahasa Arab, seperti dalam konteks pemakaian bahasa Arab, kata "ihsan" dapat dirangkai dengan preposisi huruf "lam", huruf "ila", atau huruf "ba". Apa yang didapat bila penelusurannya dengan memperhatikan konteks kebahasaaraban tersebut, dilakukan secara perspektif sosiolinguistik dan pragmatik?

Permasalahan di atas membuktikan bahwa bahasa Al-Quran yang terdiri dari kata, kalimat dan pragraf ini dapat dikaji dan ditelusuri sebagaimana teks-teks lainnya melalui unsur kebahasaannya.

Agar kajian teks bahasa Al-Quran ini lebih terfokus, hal yang akan kita jadikan variabel pengamatan utama atau objek formalnya adalah prinsip-prinsip pertuturan. Prinsip adalah 1. Asas, dasar, etika, hakikat, pokok, rukun, sendi. 2. Filsafat, kepercayaan, keyakinan, pikiran, pandangan, pendapat, pendirian, sikap. 3. Ajaran, diktum, dogma, doktrin, etika, hukum, kaidah, patokan, pedoman, pijakan. (Endarmoko, 2006:488)

Untaian wacana pertuturan banyak terdapat di dalam teks-teks kebahasaan Al-Quran, dan ini dapat ditelaah dan ditelusuri melalui unsur-unsur linguistiknya dengan menggunakan instrument etnografi komunikasi. Menurut Hymes, linguistik yang 
dapat memberikan sumbangan terhadap etnografi komunikasi itulah yang kini dikenal dengan nama sosiolinguistik. Bagi Hymes, sosiolinguistik itu memberikan sumbangan terhadap kajian komunikasi pada umumnya melalui kajian tentang organisasi alat-alat verbal. (Sumarsono, 2013:312) Oleh karena itu, kajian unsur linguistik pada teks-teks Al-Quran dalam konteks perspektif sosiolinguistik, pada gilirannya akan dapat menjawab permasalahan wacana pertuturan dalam Al-Quran.

Unsur-unsur linguistik dari bahasa Al-Quran yang mengandung wacana pertuturan diutarakan dalam bentuk struktur kebahasaan, baik perintah, larangan, maupun dalam bentuk narasi atau dialog. Struktur kebahasaan ini menjadi fokus analisa dalam menelaah dan menelusuri prinsip-prinsip bertutur yang merupakan panduan dan tatanan tingkah laku bertutur yang beretiket dan beretika. Oleh karena itu, permasalahan aspek ini perlu digali lebih dalam lagi melalui teks bahasa Al-Quran yang mengutarakan permasalahan ini.

Penelitian yang memfokuskan langsung kepada prinsip norma bertutur sebagai variabel pengamatan utama atau objek formal ini, akan memberikan faedah pada pengembangan dan perluasan dari kajian linguistik secara umum, dan khususnya dari segi asas yang menjadi pokok dasar dalam berkomunikasi atau bertutur. Kajian permasalahan bertutur yang bersumber dari objek teks bahasa Al-Quran, tentu akan memberikan faedah bagi masyarakat secara umum yang tidak bisa lepas dari aktivitas bertutur. Aktivitas bertutur yang positif dalam suatu masyarakat, tentu akan menimbulkan sebuah interaksi sosial yang harmonis, dan keharmonisan dalam berinteraksi sosial sangat dibutuhkan dalam membangun suatu bangsa dan negara.

Permasalahan yang ada dalam teks kebahasaan Al-Quran, dapat dilihat dari aspek ketentuan norma bertutur atau aturan bertutur yang bersifat mengingat pada masyarakat dan dipakai sebagai panduan, tatanan, atau kendalian tingkah laku bertutur yang sesuai dan diterima, baik secara norma agama atau norma masyarakat. Sebab dalam konteks bertutur, ada norma atau aturan yang harus ditaati, baik secara etika (moral/akhlak) atau etiket (sopan santun). Oleh karena itu, masalah difokuskan kepada prinsip norma bertutur yang menjadi pokok dasar bagi manusia dalam bertutur, dan masalah ini dapat dirumuskan sebagai prinsip bertutur dalam Al-Quran "Bagaimana prinsip normanorma bertutur yang beretiket dan beretika dalam Al-Quran ?.

Tujuan akhir hendak dicapai dalam penelitian adalah dihasilkan pemahaman dan pengetahuan konkret tentang prinsip-prinsip bertutur berdasarkan objek teks dan wacana dari bahasa Al-Quran. Tujuan penelitian tersebut disusun untuk mengungkapkan norma-norma bertutur yang beretiket dan beretika yang terdapat dalam teks kebahasaan Al-Quran.

Perkembangan kajian linguistik bahasa Arab, sepanjang sejarahnya mulai dari abad pertama hijrah hingga zaman modern sekarang ini, selalu bersentuhan dengan bahasa Al-Quran. Bahasa Al-Quran selalu menjadi objek penelitian yang dikaji dari berbagai macam tinjaun bahasa, baik aspek fonologi, morfologi, sintaksis, dan semantiknya, maupun aspek gaya bahasa dan kemukjizatannya yang sering tertuang dalam sebuah kajian yang disebut dengan "I'jāzul Lughawi (kajian penggunaan gaya bahasa yang amat indah), I'jāzul 'Adadi (kajian penggunaan jumlah bilangan kata yang amat indah), dan I'jāzul Bayāni (kajian penggunaan kalimat penjelas yang amat indah).

Penelitian secara ilmiah yang berhubungan dengan kajian linguistik dan bahasa Al-Quran menjadi objeknya, khususnya di Indonesia, telah dilakukan oleh beberapa pakar bahasa Arab. Ada yang mengkaji bahasa Al-Quran dari aspek rasionalitas bahasa Al-Quran, sebagaimana yang dilakukan oleh Ahmad Thib Raya dalam Disertasinya " Rasionalitas Bahasa AlQuran, Upaya Menafsirkan Al-Quran Dengan Pendekatan Kebahasaan ", yang kemudian dibukukan dan diterbitkan (2006). Permasalahan tersebut didasarkan atas 
pertimbangan bahwa bahasa Al-Quran memiliki fleksibilitas yang tinggi yang dapat dipahami secara rasional, baik secara tekstual maupun secara kontekstual dengan berbagai pendekatan termasuk di dalamnya dengan pendekatan kebahasaan.

Di samping itu, penelitian ilmiah terbaru yang berhubungan dengan bahasa Al-Quran dan ditinjau dari aspek relasi makna katanya adalah penelitian yang dilakukan oleh Zahrudin dengan judul Disertasinya; “ Relasi Makna Dalam AlQuran; Analisis Terhadap Kata Kata yang Memiliki Relasi Makna Dalam Al-Quran yang Diterjemahkan ke Dalam Bahasa Indonesia “ (2010).

Semua kajian terhadap bahasa Al-Quran di atas menunjukkan belum adanya penelitian ilmiah terhadap Al-Quran yang ditinjau dari aspek pertuturan yang tertuang dalam ayat-ayatnya. Namun, pertuturan bukan hal yang baru dalam kajian linguistik. Para ahli bahasa Indonesia telah mengkaji berbagai variasi bahasa yang ditinjau dari segi pemakaiannya adalah bahasa lisan. Salah satu bagian dari bahasa lisan bila ditinjau dari segi bentuknya adalah percakapan atau pertuturan, seperti A. Chaedar Alwasilah dalam bukunya; "Sosiologi Bahasa", Mansoer Pateda dalam "Sosiolinguistik", dan sebagainya.

Kajian pertuturan yang dikembangkan oleh para linguis Indonesia mengacu pada apa yang terjadi dalam bahasa Indonesia atau masyarakat Indonesia. Oleh karena itu, penelitian ini akan mengacu pada apa yang terdapat dalam Al-Quran, hanya yang membedakannya adalah lebih spesifik pada prinsip norma-norma bertutur yang terdapat dalam Al-Quran.

Penelitian ini dilandasi oleh teori Etnografi wicara atau Etnografi komunikasi yang dijabarkan oleh Dell Hymes dengan konsep akronim bahasa Inggris

SPEAKING “: (Nababan, 1991:7) atau dalam bahasa Prancis "PARLANT" (Sumarsono, 2013:335)

Penelitian ini merupakan kajian etnografi komunikasi yang bersifat kualitatif deskriptif. Etno-metodologi merupakan metodologi penelitian yang mempelajari bagaimana prilaku sosial dapat dideskripsikan sebagaimana adanya. Prilaku sosial yang dideskripsikan di sini adalah prilaku sosial dalam berbahasa atau prilaku bertutur. Oleh karena itu, agar prilaku bertutur ini dapat dideskripsikan sesuai dengan fokus permasalahan, penelitian ini berdasarkan prinsip sosiolinguistikpragmatik dengan menggunakan teori etnograpfi komunikasi yang dikembangkan oleh Dell Hymes dalam akronim "SPEAKING".

Kajian etnografi komunikasi ini dituangkan dalam bentuk kualitatif deskriptif. Artinya suatu prosedur yang menghasilkan data deskriptif berupa uraian atau gambarangambaran prilaku bertutur yang dapat diamati dan akhirnya dapat menghasilkan catatancatatan yang dapat dipertanggungjawabkan. Dengan kata lain, data diusahakan dan dikumpulkan sebanyak mungkin dan dituangkan dalam bentuk uraian dan gambaran-gambaran, dan bukan dalam bentuk angka-angka.

\section{PEMBAHASAN \\ Etiket dan Etika Bertutur}

Bertens dalam bukunya "Etika" (2013:117-118) menjelaskan bahwa norma yang menyangkut perilaku manusia, ada yang bersifat khusus, dan ada yang bersifat umum. Norma yang bersifat khusus seperti norma bahasa. Tata bahasa Indonesia adalah norma yang menentukan pemakaian bahasa dengan baik dan benar, atau justru tidak. Kalau dalam bertutur, pemakaian bahasa harus sesuai dengan norma tata bahasanya. Kalau tidak sesuai, pemakaian bahasanya tidak betul karena tidak memenuhi syarat.

Sedangkan norma yang bersifat umum adalah norma etiket dan norma etika. Norma etiket hanya menjadi tolak ukur untuk menentukan apakah perilaku manusia sopan santun atau tidak, sedangkan norma etika menentukan apakah perilaku manusia baik atau buruk dari sudut etis. Norma etika ini bisa dirumuskan dalam bentuk positif atau negatif. Dalam bentuk positif, norma etika tampak sebagai perintah yang menyatakan 
apa yang harus dilakukan, misalnya, harus menghormati orang tua atau harus mengatakan yang benar. Dalam bentuk negative, norma etika tampak sebagai larangan yang menyatakan apakah yang tidak boleh dilakukan, seperti, jangan membunuh, jangan berbohong, atau jangan menghina.

Dalam kaitannya dengan norma khusus dan umum, Bertens (2013:119) menjelaskan bahwa norma khusus harus tunduk pada norma umum. Bisa saja ada seseorang memakai bahasa Indonesia dengan baik dan benar. Dari sudut norma bahasa, apa yang dikatakannya itu memang sempurna. Tapi dengan mengatakan itu, pada kenyataannya ia memfitnah orang lain atau ia berbohong. Jadi dari sudut etis, apa yang dikatakannya itu sama sekali tidak baik dan benar. Hal seperti ini, norma bahasa pun harus tunduk pada norma etika atau moral.

Istilah "etika" dan "etiket" sering dicampuradukkan. Dalam hal ini, Bertens menjelaskan persamaan dan perbedaan antara dua istilah tersebut (2013:7-8). Persamaannya bahwa "etika" dan "etiket" menyangkut perilaku manusia dan mengatur perilaku tersebut secara normatif. Artinya memberi norma bagi perilaku manusia, apa yang harus dilakukan atau tidak boleh dilakukan. Sedangkan perbedaannya adalah:

1. Etiket menyangkut cara suatu perbuatan harus dilakukan manusia. Misalnya cara menyerahkan sesuatu kepada orang lain, harus menggunakan tangan kanan, dan dianggap melanggar etiket bila menyerahkannya dengan tangan kiri. Sementara, etika tidak terbatas pada cara melakukan suatu perbuatan, tetapi etika memberi norma tentang perbuatan itu sendiri. Artinya, apakah perbuatan itu boleh dilakukan atau tidak. "Jangan berbohong", "jangan menghina", "jangan mencuri" merupakan suatu norma etika.

2. Etiket hanya berlaku dalam pergaulan. Bila tidak ada orang lain hadir atau tidak ada saksi mata, etiket tidak berlaku. Misalnya cara makan atau berpakaian. Dianggap melanggar etiket bila makan sambil meletakkan kaki di atas meja. Tapi kalau makan sendiri, tidak dianggap melanggar etiket. Sebaliknya, etika selalu berlaku, juga kalau tidak ada saksi mata. Etika tidak tergantung pada hadir tidaknya orang lain.

3. Etiket bersifat relative. Yang dianggap tidak sopan dalam suatu kebudayaan, bisa saja dianggap sopan dalam kebudayaan lain. Misalnya, makan dengan tangan atau bersendawa waktu makan. Sementara, etika jauh lebih absolut. "Jangan berbohong", "jangan mencuri", "jangan menghina", "jangan menyakiti orang lain" merupakan prinsip-prinsip etika yang tidak bisa ditawar-tawar atau mudah diberi "dispensasi".

4. Etiket hanya memandang manusia dari segi lahiriah saja, sedang etika menyangkut manusia dari segi dalam. Bisa saja orang tampil sebagai "musang berbulu ayam", dari luar sangat sopan dan santun, tetapi di dalam penuh kebusukan.

Dalam konteks bertutur, ada norma atau aturan yang harus ditaati, baik secara etika (moral/akhlak) atau etiket (sopan santun). Tesaurus Bahasa Indonesia menjelaskan (Endarmoko, 2006:176) bahwa kata "etika" berarti adab, akhlak, budi pekerti, kebajikan, kesusilaan, kultur, moral, tata susila. Dan kata "etiket" berarti adab, kepatutan, kesopanan, sopan santun, tata karma, formalitas, adat, kebiasaan, konvensi, tata cara. (Endarmoko, 2006:176). Dalam Kamus Lengkap Bahasa Indonesia, kata "etiket" bermakna adat kesopanan dalam masyarakat. (Hizair, 2013:183).

\section{Norma Norma Etiket Bertutur Dalam Al-Quran}

Berdasarkan data-data yang terdapat di dalam Al-Quran, norma etiket bertutur ada yang berbentuk positif dan ada yang berbentuk negatif. Hal ini dapat diklasifikasikan dan dijabarkan sebagai berikut:

\section{Etiket bertutur ditinjau dari aspek "End"}

Artinya tatakrama bertutur dengan memperhatikan maksud, tujuan, atau efek yang ingin dicapai. Berdasarkan temuan penelitian bahwa norma etiket bertutur dari 
aspek ini, terdapat dua (2) prinsip bertutur: Pertama, Jangan bertutur sok tahu, Kedua, Jangan berdebat untuk membela yang tidak pantas untuk dibela. Berikut ini pembahasan salah satu dari prinsip tersebut:

\section{Prinsip etiket bertutur: Jangan bertutur sok tahu} berfirman :

Q.S. Al-Baqarah (2) : 140, Allah swt

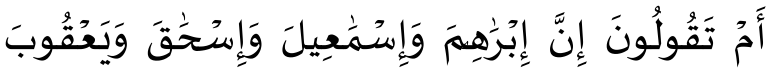

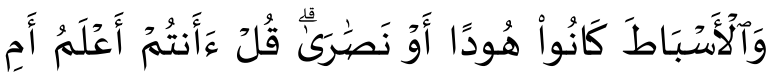

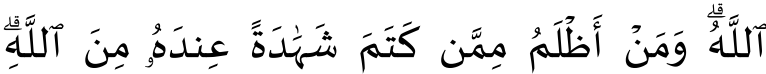

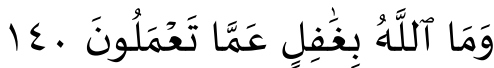

Ataukah kamu (hai orang-orang Yahudi dan Nasrani) mengatakan bahwa Ibrahim, Isma'il, Ishaq, Ya'qub dan anak cucunya, adalah penganut agama Yahudi atau Nasrani?" Katakanlah: "Apakah kamu yang lebih tahu ataukah Allah, dan siapakah yang lebih zhalim dari pada orang yang menyembunyikan kesaksian dari Allah yang ada padanya?" dan Allah sekali-kali tidak lengah terhadap apa yang kamu kerjakan. (Q.S. Al-Baqarah (2) : 140)

Ayat ini berbicara mengenai tuturan orang-orang Yahudi dan Nasrani yang menyatakan bahwa Ibrahim as. dan kedua putranya Ismail as dan Ya'kub as. serta anak dan cucunya adalah penganut agama Yahudi dan Nasrani. Apa yang mereka katakan itu berbeda dengan informasi Allah bahwa para Nabi tersebut menganut agama Tauhid, yang jauh sebelum datangnya Nabi Musa as. dan Nabi Isa as.

Satu hal yang perlu dicermati dari ayat di atas adalah firman Allah pada kalimat

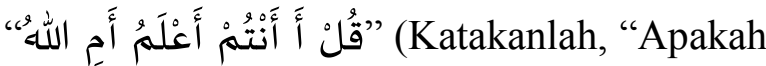
kalian yang lebih mengetahui ataukah Allah"). Penggalan ayat ini menunjukkan bahwa orang-orang Yahudi dan Nasrani menganggap dirinya paling mengetahui tentang para nabi yang agung itu, padahal mereka tidak mengetahui hal tersebut sama sekali. Penggalan ayat ini merupakan ejekan untuk mereka yang sok tahu. Bagi siapa saja tak mungkin akan berkata bahwa manusia lebih tahu dari pada Allah.

Satu pelajaran yang dapat dipetik dari ayat di atas adalah bahwa pengetahuan manusia terbatas. Maka dari itu, suatu perilaku yang tidak beretiket, bila ada orang yang bertutur bahwa dia yang paling tahu tentang suatu perkara dari pada orang lain yang memang ia ahlinya dalam perkara tersebut. Bahkan pertuturan seperti ini menunjukkan bahwa penuturnya adalah orang sombong, menganggap rendah pihak lain. Kesombongan seperti ini akan menjerumuskan orang itu kepada sikap-sikap negatif, seperti egois dan terpedaya dengan dirinya sendiri.

Orang yang mempunyai sifat sombong cenderung meremehkan kawan-kawan sesamanya. Bila ia telah menguasai pengetahuan tertentu, maka ia akan menghina dan mencela kawan-kawanya yang ketinggalan pengetahuannya, (Al-Hasyimi, 2009:13)

Sebagai contoh, simak cerita yang diriwayatkan dari Ibnu Abbas bahwasanya Umar bin Khaththab memanggil para pengikut perang Badar dan memanggilku bersamanya. Sebagian mereka tidak suka dengan demikian itu, dan berkata, "Beliau mengizinkan anak muda ini bersama kita, padahal kita juga memiliki anak yang sama dengannya". Umar berkata kepada mereka, "Dia adalah seorang yang seperti anda ketahui, yaitu sangat cerdas dan akalnya sangat kuat".

Suatu hari Umar memanggil mereka dan memanggilku bersamanya. Beliau bertanya kepada mereka mengenai surat " (Apabila telah datang pertolongan Allah dan kemenangan) (Q.S. An-Nashr (110) : 1). Mereka menjawab, "Allah memerintahkan kepada Nabi-Nya, apabila dia berhasil melakukan penaklukan agar beristighfar dan bertaubat kepadaNya.

Umar berkata, "Bagaimana pendapatmu, wahai Ibnu Abbas"!. Aku menjawab, "Bukan demikian, tetapi Allah memberitahukan kepada Nabi-Nya mengenai datangnya ajal beliau dan berfirman, 
"Apabila telah datang pertolongan Allah dan kemenangan itu adalah tanda-tanda kematianmu. Firman Allah, "Maka bertasbihlah dengan memuji Tuhanmu dan mohonlah ampun kepadaNya. Sesungguhnya Dia adalah Maha Penerima Taubat".

Umar berkata, "Aku tidak mengetahui tafsirnya kecuali seperti yang anda katakan". (Ibrahim, 2013 : 55-56)

\section{Etiket bertutur ditinjau dari aspek "Act sequence"}

Artinya tatakrama bertutur dengan memperhatikan bentuk dan isi pertuturan. Berdasarkan temuan penelitian bahwa norma etiket bertutur dari aspek ini, terdapat tiga (3) prinsip bertutur, Pertama, Jangan bertutur kata yang tidak berguna. Kedua, Jangan ikut terlibat dalam pertuturan yang bathil. Ketiga: Keharusan bertutur untuk saling nasehatmenasehati. Berikut ini pembahasan salah satu dari prinsip-prinsip tersebut:

\section{Prinsip etiket bertutur:}

Jangan bertutur kata yang tidak berguna berfirman :

Q.S. Al-Mu'minun (23) : 3, Allah swt

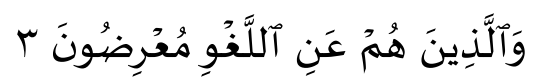

Dan orang-orang yang menjauhkan diri dari (perbuatan dan perkataan) yang tidak berguna, (Q.S. Al-Mu'minun (23) : 3)

Ayat ini menunjukkan bahwa katakata yang keluar dari seorang mu'min, haruslah kata-kata pilihan yang mempunyai manfaat, baik bagi dirinya maupun bagi orang lain.

Kata “اللَغْو" adalah ucapan-ucapan yang mengandung dosa. Kata "مُعْرِضُوْنَ" terambil dari kata "العِرضض bermakna samping, yakni seseorang yang tidak memberi perhatian kepada sesuatu atau dia mengesampingkannya. Artinya ayat ini menunjukkan bahwa perhatian orang mu'min tidak tertuju kepada hal-hal yang tak memberi manfaat, sebagaimana sabda Rasulullah saw menegaskan bahwa sebaikbaik muslim adalah orang yang meninggalkan sesuatu yang tak berguna.
Oleh karena itu, yang dianjurkan kepada orang-orang mu'min adalah bertutur kata yang memberi manfaat, yaitu pertuturan yang baik. Pertuturan yang baik merupakan perilaku berbahasa yang berdampak positif, baik bagi si penutur maupun bagi mitra tuturnya. Perilaku berbahasa yang mulia ini selalu ditekankan oleh Rasulullah saw sebagaimana sabda beliau menegaskan:

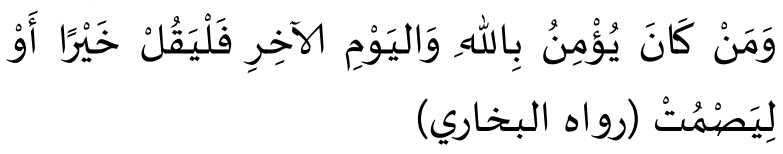

Siapa saja yang beriman kepada Allah dan hari Kiamat, hendaklah ia mengatakan yang baik atau diam (HR. Bukhari) (Ali, 2013:25)

\section{Kalimat “ وَمَنْ كَانَ يُؤْمِنْ بِاللَهـ وَالَيَوْمِ}

"الآخِرِ menunjukkan bahwa kesempurnaan iman seseorang dikaitkan dengan perilaku berbahasanya yang merupakan sebuah syarat. Artinya keimanan seorang belum sempurna bila ia tidak bertutur kata yang baik, dan dia akan disebut sempurna imannya, bila ia selalu menghiasi mulutnya dengan kata-kata yang baik dan menahan diri dari mengeluarkan kata-kata yang buruk.

Hal ini sejalan pula dengan hadits lainnya yang diriwayatkan oleh Imam Ahmad dari sahabat Anas r.a. bahwa Rasulullah saw bersabda:

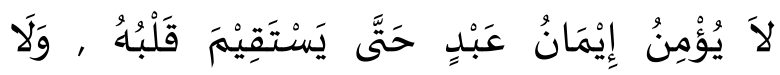

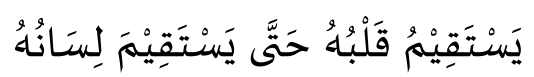

"Iman seseorang tidak akan sempurna kecuali bila hatinya lurus (bersih), dan hati seseorang tidak akan lurus kecuali jika lisannya telah terjaga (dari ucapan-ucapan yang kotor lagi keji) (Al-Hasyimi, 2009:69)

Dalam hadits lainnya, Rasulullah saw bersabda:

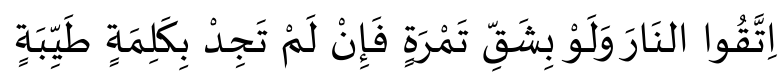

$$
\text { (رواه البخاري ومسلم) }
$$

"Lindungilah diri kalian dari neraka meskipun hanya dengan (menyedekahkan) sebiji kurma, bila tidak punya maka cukup dengan tutur kata yang baik". (HR. Bukhari Muslim). (Al-Hasyimi, 2009:79) 
Hadits di atas menuntut untuk tidak melontarkan pertuturan yang tidak berguna atau tidak memberi manfaat apa-apa dari pertuturannya itu. Sebagai contoh, debat kusir tentang masalah sepele atau tidak ada dasarnya, seperti memperdebatkan seekor serigala yang yang memakan Nabi Yusuf, mulai dari ciri-ciri binatang tersebut yang berada di padang pasir, warna bulunya, taringnya hingga badannya besar atau kecil.

Perdebatan semacam itu termasuk pertuturan yang tidak berguna. Kenapa? Karena cerita serigala yang memakan Nabi Yusuf adalah sebuah kebohongan belaka yang dilontarkan oleh saudara-saudara Yusuf untuk mengelabui ayahnya, Nabi Ya'kub. Oleh karena itu, pertuturan itu adalah pertuturan yang sia-sia dan tidak ada manfaatnya.

\section{Etiket bertutur ditinjau dari aspek "Key"}

Artinya tatakrama bertutur dengan memperhatikan metode dan cara penyampaiannya yang tepat dan efektif. Berdasarkan temuan penelitian bahwa norma etiket bertutur dari aspek ini, terdapat tiga (3) prinsip bertutur: Pertama, Penggunaan kata "insya Allah" untuk kejadian esok atau akan datang. Kedua, Penggunaan suara lunak dalam bertutur dan tidak membentak. Ketiga, Keseriusan dalam bertutur dan tidak senda gurau. Berikut ini pembahasan salah satu dari prinsip-prinsip tersebut:

\section{Prinsip etiket bertutur: \\ Keseriusan dalam bertutur dan tidak senda gurau}

Penutur dituntut untuk bertutur kata serius, tidak dengan bersenda gurau dalam konteks pertuturan penting yang membutuhkan keseriusan.

Q.S. Ath-Thariq (86) : 13-14, Allah swt berfirman :

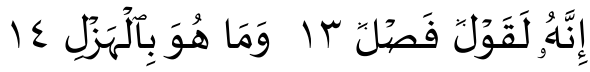

Sesungguhnya Al Quran itu benar-benar firman yang memisahkan antara yang hak dan yang bathil. Dan (Al-Quran) itu bukanlah senda gurauan. (Q.S. Ath-Thariq (86) : 13-14)
Ayat ini menjelaskan bahwa Al-Quran adalah firman Allah yang benarbenar memberi putusan sekaligus memisahkan antara yang haq dan yang bathil, serta dia bukanlah senda gurau dalam arti segala ucapan yang tidak bermanfaat dan tidak berdampak positif.

Satu hal yang perlu dicermati dari ayat di atas dalam konteks etiket bertutur adalah bahwa bertutur itu memang seharusnya serius dalam konteks pertuturan yang memang membutuhkan keseriusan, seperti ketika memberi nasihat.

Keseriusan itu karena memang substansi yang dibicarakannya begitu penting, sehingga tidak etis jika dicampuri dengan senda gurau, apalagi bila berlebihan, akan menghilangkan atau mengurangi substansi tersebut.

Namun demikian, bukan berarti bahwa senda gurau itu tidak boleh. Dalam konteks tertentu senda gurau itu diperbolehkan, bahkan Rasulullah saw adalah orang suka bercanda dan senda gurau, namun tetap dalam batas-batas kewajaran dan tidak mengandung unsur kebohongan. Beliau bersabda: "Saya senang bercanda, namun yang saya katakan adalah kebenaran". (Al-Hasyimi, 2009:83)

Sebagai contoh canda ringan dan menarik, ada seorang wanita tua dari kaum Anshar menghadap Rasulullah saw dan berkata: "Ya Rasulullah, saya mohon engkau berdoa kepada Allah supaya saya masuk surga". Rasulullah saw menjawab, "Tidakkah kamu tahu bahwa surga tidak dihuni oleh orang-orang yang sudah tua?. Mendengar sabda Rasulullah saw, wanita tersebut menangis. Melihat hal ini, Rasulullah saw tersenyum dan bersabda, "Bukankah kamu pernah membaca firman Allah swt. "Sesungguhnya Kami menciptakan mereka (wanita-wanita penghuni surga) dengan langsung, dan Kami jadikan mereka gadisgadis perawan, penuh cinta lagi sebaya umurnya". (Al-Hasyimi, 2009:83)

Sebagai contoh lainnya, Istri Nabi saw, Aisyah r.a. berkata bahwa suatu ketika aku memasak makanan dan memberikannya kepada Rasul saw, yang ketika itu berada 
bersama istri beliau, Saudah. Aisyah mengharap Saudah r.a. ikut makan , tapi ia enggan karena tidak sesuai dengan seleranya. Aisyah bersikeras sambil berkata, "Demi Allah, engkau harus makan, kalau tidak, akan ku kotori wajahmu dengan makanan ini." Karena Saudah bersikeras untuk tidak makan, Aisyah mengambil sebagian dari makanan itu dan menempelkannya ke wajah Saudah. Saudah pun melakukan hal sama ke wajah Aisyah sambil tertawa. Rasul saw yang melihatnya pun ikut tertawa. (Shihab, 2009:320, jilid 8)

Jadi, berdasarkan hadits Rasulullah saw bahwa bertutur kata seraya bersenda gurau adalah sesuatu pertuturan yang diperbolehkan selama dalam batas-batas kewajaran, dan tidak mengandung sesuatu yang menghina atau mengejek. Namun, jika yang dibicarakan adalah sesuatu yang penting untuk diperhatikan, sudah sewajarnya hal itu disampaikan dalam pertuturan yang serius, seperti pertuturan dari sebuah nasihat, dan jika diselipkan dengan senda guran, justru substansi akan hilang.

Sebagai contoh, simak nasihat Habil kepada Qabil berikut ini:

"Saudaraku, kau telah bertindak sewenang-wenang dan menyimpang dari kebenaran. Tekadmu salah, keinginanmu keliru, dan pandanganmu jauh dari kebenaran. Tidak ada hal yang paling layak engkau lakukan saat ini kecuali memohon ampunan kepada Allah dan kembali dari kesesatanmu. Namun, jika tekadmu sudah bulat dan keputusanmu telah mantap, lakukanlah apa yang ingin kau lakukan. Aku serahkan segala urusanku kepada Allah. Aku tak mau menentang kehendakNya dan aku tak mau hatiku disentuh pengaruh yang membuatku membangkang kepadaNya. Lakukanlah apa yang ingin kau lakukan dan tanggung lah segala dosa serta akibatnya. Jika kau ikuti bujukan hawa nafsu, niscaya kau akan menjadi penghuni neraka. Itulah balasan bagi orang yang berbuat aniaya". (Maula, 2015:29)

\section{Norma Norma Etika Bertutur Dalam Al-Quran}

Berdasarkan data-data yang terdapat di dalam Al-Quran, norma etika bertutur ada yang berbentuk positif dan ada yang berbentuk negatif. Hal ini dapat diklasifikasikan dan dijabarkan sebagai berikut:

\section{Etika bertutur ditinjau dari aspek "End".}

Artinya tatacara bertutur dengan memperhatikan maksud, tujuan, atau efek yang ingin dicapai. Berdasarkan temuan penelitian bahwa norma etika bertutur dari aspek ini, terdapat tiga (3) prinsip bertutur: Pertama, Jangan bertutur kata yang menyakiti mitra tutur. Kedua, jangan bertutur kata menyesatkan dan memperolok-olok, serta jangan memnaggil denga gelar yang buruk. Ketiga, Jangan menyombongkan diri atau membanggakan diri kepada mitra tutur. Berikut ini pembahasan salah satu dari prinsip tersebut:

\section{Prinsip etika bertutur:}

\section{Jangan bertutur kata yang menyakiti hati mitra tutur} berfirman :

Q.S. Al-Baqarah (2) : 262, Allah swt

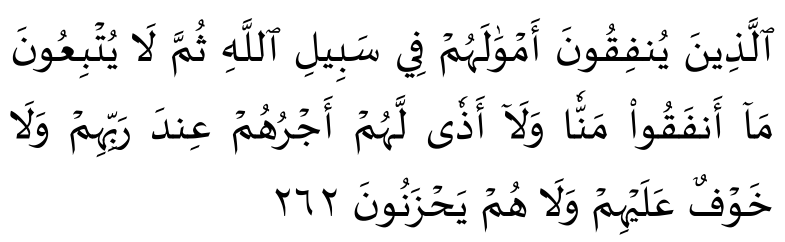

Orang-orang yang menafkahkan hartanya di jalan Allah, kemudian mereka tidak mengiringi apa yang dinafkahkannya itu dengan menyebut-nyebut pemberiannya dan dengan tidak menyakiti (perasaan si penerima), mereka memperoleh pahala di sisi Tuhan mereka. Tidak ada rasa takut pada mereka dan tidak (pula) mereka bersedih hati. (Q.S. Al-Baqarah (2) : 262)

Ayat di atas menjelaskan bahwa pemberian nafkah kepada orang lain yang direstui Allah dan mendapatkan lipatan pahala adalah tidak menyebut-nyebut pemberiannya dan tidak pula menyakiti hati orang yang diberi. 
Kata "مَنَّ" yang artinya menyebut-

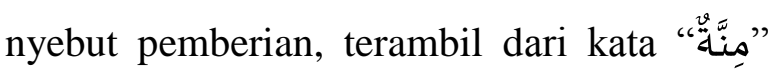

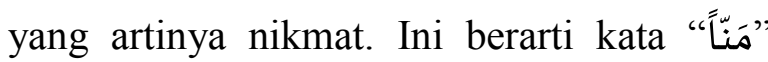
adalah menyebut-nyebut nikmat kepada yang diberi serta membanggakannya. Sementara, kata “أَذَي bermakna gangguan. Artinya menyebut-nyebut pemberian pun merupakan gangguan, (Shihab, 2009:691, jilid 1)

Berdasarkan dua kata tersebut di atas, dapat dipahami bahwa kata "“َّ a adalah menyebut-nyebut nikmat dihadapan orang yang diberi, sedang kata " "أَذَي adalah menyebut-nyebut nikmat kepada orang lain sehingga yang diberi merasa terganggung perasaannya karena malu dan hilang mukannya.

Jadi, yang dituntut dari ayat di atas adalah tidak melakukan kedua keburukan itu, bukan hanya pada saat pemberian berlangsung, tetapi juga di kemudian hari setelah masa pemberian. Memang, ada orang, pada saat pemberian, memberikan nikmatnya secara tulus, bahkan mungkin rahasia, atau dengan kata bahasa agama, memberi sesuatu tanpa diketahui oleh tangan kirinya. Tetapi beberapa kemudian, dia menceritakan pemberiannya kepada orang lain yang mengakibatkan orang yang diberi merasa malu dan tersinggung perasaannya.

Hal ini dipertegas lagi pada ayat selanjutnya, yaitu Q.S. Al-Baqarah (2) : 263, Allah swt berfirman :

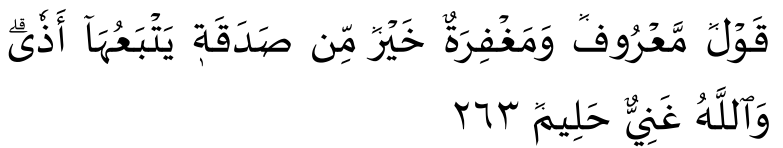

Perkataan yang baik dan pemberian maaf lebih baik dari sedekah yang diiringi dengan tindakan yang menyakiti (perasaan si penerima). Allah Maha Kaya lagi Maha Penyantun. (Q.S. Al-Baqarah (2) : 263)

Ayat ini menunjukkan bahwa ucapan yang baik lebih terpuji dari pada memberi dengan menyakitkan hati. Berdasarkan ayat ini, dapat disimpulkan bahwa memberi dengan menyakiti hati adalah aktivitas yang menggabungkan kebaikan dan keburukan.
Oleh karena itu, Allah melarang aktivitas penggabungan seperti ini sebagaimna tergambar dari ayat berikutnya, yaitu Q.S. Al-Baqarah (2) : 264, Allah swt berfirman :

Wahai orang-orang yang beriman, janganlah kamu menghilangkan (pahala) sedekahmu dengan menyebut-nyebutnya dan menyakiti (perasaan si penerima), seperti orang yang menafkahkan hartanya karena riya kepada manusia dan dia tidak beriman kepada Allah dan hari kemudian. Maka perumpamaan orang itu seperti batu licin yang di atasnya ada debu, kemudian batu itu ditimpa hujan lebat, lalu batu itu menjadi licin kembali (tidak berdebu). Mereka tidak memperoleh sesuatu apapun dari apa yang mereka kerjakan; dan Allah tidak memberi petunjuk kepada orang-orang kafir. (Q.S. Al-Baqarah (2) : 264)

Satu hal yang amat menarik untuk dicermati dari ayat 264 di atas adalah dua perilaku buruk, yaitu memberi dengan menyebut-nyebut pemberiannya dan memberi dengan menyakiti hati si penerima, disamakan dengan dua perilaku buruk lainnya, yaitu pemberian dengan pamrih untuk mendapatkan pujian dan tidak beriman kepada Allah dan hari Kiamat.

Artinya orang yang bersedekah disertai dengan menyebut-nyebut dan menyakiti, keadaannya sama dengan orang yang berinfak karena riya atau pamrih dan tidak beriman. Keadaan mereka semua seperti itu menunjukkan bahwa amal mereka menjadi sia-sia tanpa bekas. Kesia-siaan amal mereka ini diperumpamakan seperti batu licin yang di atasnya ada tanah (yaitu perilaku mereka), lalu ditimpa hujan lebat, maka batu yang licin itu menjadi bersih, tidak meninggalkan sedikitpun tanah atau debu.

Jadi, satu hal yang dapat diambil pelajaran dari ayat-ayat di atas adalah bertutur kata yang menyakiti hati mitra tutur, dapat menghilangkan segala amal ibadanya. Artinya amal ibdahnya menjadi sia-sia sebagaimana sabda Rasulullah saw menegaskan hal itu:

Abu Hurairah ra. Meriwayatkan bahwa Nabi saw ditanya: "wahai Rasulullah 
(Bagaiman pendapat anda mengenai) seorang perempuan yang rajin shalat di malam hari, dan melakukan puasa di siang hari, namun mulutnya sering lancang hingga menyakiti hati tetangganya?". Rasulullah saw menjawab: "Tidak ada kebaikan pada dirinya. Dia masuk Neraka". Kemudiam beliau ditanya lagi: (bagaimana pendapat anda mengenai) seorang perempuan yang menjalankan shalat wajib, puasa Ramadhan, menyedekahkan potongan keju padahal dia tak punya lainnya, serta mulutnya tidak pernah membuat sakit hati tetanggatetangganya?".Rasul saw menjawab: "Dia berada di surga". (HR. Ahmad dan AlHakim) (Al-Hasyimi, 2009:74).

Berkenaan dengan perilaku orang yang menyakiti hati orang lain, ada data yang menunjukkan bahwa dia diancam oleh Allah swt sebagaimana firmanNya dalan Q.S. Al-Ahzab (33) : 57-58:

Sesungguhnya orang-orang yang menyakiti Allah dan Rasul-Nya. Allah akan melaknatinya di dunia dan di akhirat, dan menyediakan baginya siksa yang menghinakan. Dan orang-orang yang menyakiti orang-orang mukmin dan mukminat tanpa kesalahan yang mereka perbuat, maka Sungguh, mereka telah memikul kebohongan dan dosa yang nyata. (Q.S. Al-Ahzab (33) : 57-58)

Ayat ini berbicara tentang ancaman yang ditujukan kepada mereka yang menyakiti Rasulullah dan kaum muslimin muslimat. Orang yang menyakiti kaum muslimin muslimat berarti pula menyakiti Rasul saw. Sebenarnya, dengan redaksi "menyakiti Allah" bukan menunjukkan makna sebenarnya, karena tidak ada seorang pun yang dapat menyakiti Allah. Oleh karena itu, penggabungan nama Allah dan RasulNya pada ayat di atas bertujuan untuk menggambarkan bahwa menyakiti hati Rasul saw mengundang murka Allah. Di samping itu, penggabungan ini mengisyaratkan bahwa menyakiti Rasul saw dipersamakan Allah dengan menyakiti diriNya, dan dengan demikian, yang akan membalas dengan siksaan yang menghinakan adalah Allah sendiri, baik di dunia maupun di akhirat.
Sebagai contoh dari pertuturan yang menyakiti mitra tutur, seperti tuturan yang mempermalukan mitra tutur. Dalam arti menghina dan merendahkan mitra tutur. Simak contoh berikut ini: (Chaer, 2010 : 109)

(1) Anak itu bukan malas, melainkan goblok.

(2) Orang lain menyumbang sedikitnya seratus ribu, kenapa kamu cuma lima ribu

Dua buah tuturan di atas adalah menghina dan merendahkan mitra tutur, dan ini melanggar prinsip kesantunan dan tidak beretika. Agar tuturan di atas menjadi santun dan beretika, redaksinya harus dirubah dengan tuturan yang bersifat tidak mempermalukan mitra tutur. Simak contoh berikut ini: (Chaer, 2010:110)

(1) Anak ibu sebetulnya cukup pandai, hanya kadang-kadang kurang tekun

(2) Allah tidak melihat sumbangan itu dari besar kecilnya, melainkan terutama dari keikhlasan dan ketulusan pemberiannya.

\section{Etika bertutur ditinjau dari aspek "Act sequence"}

Artinya tatacara bertutur dengan memperhatikan bentuk dan isi pertuturan. Berdasarkan temuan penelitian bahwa norma etika bertutur dari aspek ini, terdapat tujuh (7) prinsip bertutur: Pertama, Bertutur kata sesuai hati nurani. Kedua: Jangan bertutur kata memfitnah. Ketiga, Jangan bertutur kata dusta. Keempat, Bertutur kata jujur untuk menegakkan keadilan. Kelima, Bertutur kata dengan amanah sesuai dengan yang diamanahi, tidak dilebih-lebihkan dan tidak dikurangi. Keenam: Jangan bertutur cacimaki dan mencela. Ketujuh, Jangan bertutur mempergunjingkan orang lain. Berikut ini pembahasan salah satu dari prinsip-prinsip tersebut:

\section{Prinsip etika bertutur:}

\section{Jangan bertutur kata memfitnah}

$$
\text { Q.S. An-Nur (24) : 11-12, }
$$

Allah swt berfirman : 


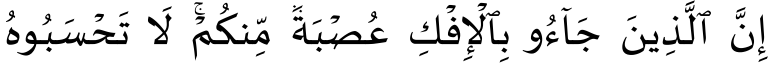

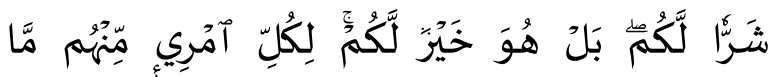

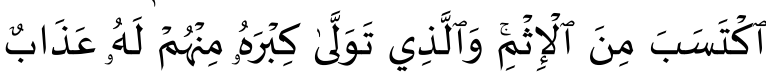

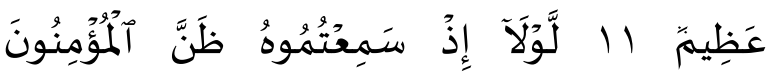

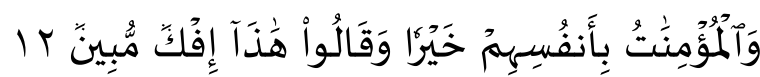

Sesungguhnya orang-orang yang membawa berita bohong itu adalah dari golongan kamu juga. janganlah kamu mengiira bahwa berita bohong itu buruk bagi kamu bahkan ia adalah baik bagi kamu. setiap orang dari mereka mendapat balasan dari dosa yang dikerjakannya. dan barangsiapa di antara mereka yang mengambil bagian yang terbesar (dalam penyiaran berita bohong itu) baginya azab yang besar. Mengapa orangorang mukmin dan mukminat tidak bersangka baik terhadap diri mereka sendiri ketika kamu mendengan berita bohong itu dan berkata: "Ini adalah suatu berita bohong yang nyata." (Q.S. An-Nur (24) : 11-12)

Ayat ini mengecam orang-orang yang menuduh istri Rasulullah saw, Aisyah, tanpa bukti. Mereka menyebarluaskan dengan sengaja berita bohong yang keji itu menyangkut kehormatan keluarga Nabi Muhammad saw. Ayat ini benar-benar mengecam bahwa tiap orang dari mereka yang menyebarkan rumor itu akan memperoleh balasan sesuai dengan kadar apa yang dia kerjakan dari dosa isu buruk itu, dan bagi siapa yang menjadi sumber dalam penyebaran berita fitmah itu, ia akan mendapatkan azab di akhirat nanti.

Peristiwa kebohongan besar atau fitnah keji yang dimaksud oleh ayat di atas adalah tertuju kepada istri Nabi saw, Aisyah. Secara singkat kejadiannya setelah pertempuran Bani Al-Musthaliq. Nabi saw mengizinkan pasukannya untuk kembali menjelang fajar. Ketika akan berangkat bersama rombongan, tiba-tiba Aisyah sadar bahwa kalungnya hilang sehingga beliau terpaksa kembali mencarinya. Setelah menemukannya, beliau kembali menuju tempat rombongan dan mendapati mereka telah berangkat. Kemudian beliau menanti di tempat pemberangkatan dengan harapan kafilah akan datang menjemputnya. Dalam saat yang sama, seorang sahabat, Shafwan bin Al-Muaththil As-Sulami, yang mendapat tugas dari Nabi saw untuk mengamati pasukan musuh jangan sampai ada yang membuntuti pasukan muslimin, dan setelah aman, ia segera menyusul untuk bergabung dengan mereka. Kemudian ia menemukan Aisyah yang ketinggalan rombongan sedang tidur, kemudian ia memerintahkan untanya untuk duduk sebagai isyarat kepada Aisyah agar mengendarainya, dan ia berjalan sambil menuntun untanya. Di siang hari, mereka menemukan pasukan muslimin yang di dalamnya terdapat tokoh kaum munafik, Abdullah bin Ubay bin Salul. Dialah yang mengambil inisiatif dan berperan besar dalam memutarbalikkan fakta dengan menuduh Aisyah menjalin hubungan mesra denga Shafwan. Dari sini, isu fitnah menyebar bagaikan api dalam sekam, dan akhirnya didengar pula oleh Rasulullah saw, dan yang terakhir mendengarnya adalah Aisyah r.a. (Shihab, 2009:491, jilid 8)

Satu hal yang dapat diambil sebagai pelajaran dari peristiwa fitnah ini adalah informasi dari ayat 12 surat An-Nur ini yang menjelaskan sikap kaum muslimin ketika isu itu merebak. Di antara mereka ada tiga kelompok, yaitu: Pertama, kelompok yang terdiam, tidak membenarkan dan tidak pula membantah. Kedua, kelompok yang membicarakannya sambil bertanya tanya tentang kebenarannya atau sambil menampakkan keheranannya. Ketiga, kelompok yang sejak semula tidak mempercayainya dan menyatakan kepercayaannya tentang kesucian Aisyah.

Ayat 12 ini mengecam kelompok pertama, dan juga kelompok kedua. Kedua kelompok ini benar-benar tidak beretika, karena mereka tidak bersangka baik terhadap saudara-saudara mereka yang dicemarkan namanya, padahal yang dicemarkan itu adalah istri Nabi saw dan martabat keluarga beliau. Mestinya mereka melakukan pembelaan, paling tidak pembelaan pasif dengan berkata, "هَذًَا إِفْكُ مُبْينْن" (ini adalah berita bohong yang nyata). Artinya Isu itu sangat meragukan kebenarannya. 
Sebagai contoh lainnya dari fitnah yang keji, juga tergambar dalam Q.S. AnNisa (4) : 156, Allah swt berfirman :

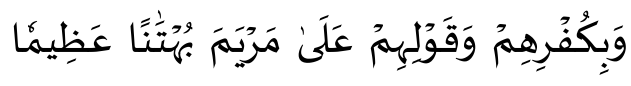

107

Dan (Kami hukum juga) karena kekafiran mereka (terhadap Isa) dan tuduhan mereka yang keji (zina) terhadap Maryam, (Q.S. AnNisa (4) : 156)

Ayat ini menjelaskan bagaimana orang-orang Yahudi menuduh Maryam dengan tuduhan yang amat keji, yaitu menuduh berzina, dan anaknya, Nabi isa as, lahir dari dari perzinaan, padahal telah terbukti kesucian Maryam dan Isa a.s. melalui aneka bukti dan mukjizat.

Mudah-mudahan, ayat tersebut di atas dapat dijadikan pelajaran bagi kaum muslimin seluruhnya untuk berhati-hati dalam menerima dan membedakan isu, apalagi penyebarnya seorang fasiq.

Sebagai contoh, simak cerita Irfan Hamka dalam bukunya "Ayah" tentang tuturan fitnah yang dilontarkan kepada ayahnya (Buya Hamka), ketika beliau terpilih sebagai Ketua Umum Majlis Ulama Indonesia.

Seorang mubaligh pernah mengatakan, "Hamka bukan milik umat lagi. Dia telah menjual dirinya dengan uang satu miliar untuk dapat menduduki jabatan mulia itu. Dia telah menjadi orang istana". (2013 : 254)

Itulah fitnah yang dilontarkan oleh seorang mubaligh terhadap Buya Hamka. Tuturan dari seorang mubaligh tersebut tidak mencerminkan etika yang baik, atau dirinya tidak beretika baik padahal ia memahami bagaimana ajaran Islam mengajarkan kepadanya.

\section{Etika bertutur ditinjau dari aspek "Key"}

Artinya tatacara bertutur dengan memperhatikan metode atau cara penyampaiannya yang tepat dan efektif. Berdasarkan temuan penelitian bahwa norma etika bertutur dari aspek ini, terdapat dua (2) prinsip bertutur, Pertama: Bertutur kata dengan sikap rendah hati dan lemah lembut.
Kedua, jangan bertutur kata berdasarkan hawa nafsu dan prasangka. Berikut ini pembahasan salah satu dari prinsip tersebut:

\section{Prinsip etika bertutur:}

\section{Jangan bertutur kata berdasarkan hawa nafsu dan prasangka}

Q.S. An-Najm (53) : 3-4, Allah swt berfirman:

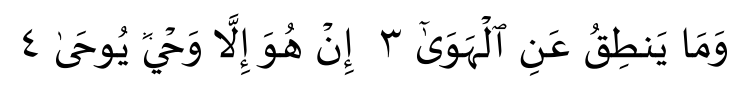

Dan Tidaklah yang diucapkannya itu (Al-Quran) menurut kemauan hawa nafsunya. Ucapannya itu tiada lain hanyalah wahyu yang diwahyukan (kepadanya). (Q.S. An-Najm (53) : 3-4)

Ayat ini menegaskan bahwa Rasulullah saw bertutur tidak berdasarkan hawa nafsu, tetapi apa yang disampaikannya, tiada lain hanyalah wahyu yang diwahyukan kepadanya.

Kata "ما ينطق" yang artinya tiadalah ia berucap, menunjukkan dari segi redaksional mencakup apapun yang disampaikan Nabi Muhammad saw. Ada hadits bahwa Abdullah bin Amr berkata: "Aku tadinya menulis segala sesuatu yang kudengar dari Rasulullah saw, tetapi (temantemanku dari) suku Quraisy melarangku. Mereka berkata: "kamu menulis segala sesuatu yang kamu dengar dari Rasulullah, padahal beliau adalah manusia yang berbicara ketika marah atau rela,". Maka aku, ibn Amr, menghentikan penulisan dan menyampaikan hal tersebut kepada Rasulullah saw, lalu beliau bersabda: "Tulislah! Demi Allah yang jiwaku berada dalam genggamanNya, tidak keluar (satu ucapan dariku) kecuali haq atau kebenaran". (Shihab, 2009:173, jilid 13)

$$
\text { Kata "الهوى" berarti kecenderungan }
$$

hati kepada sesuatu tanpa pertimbangan akal yang sehat. Artinya bila kata ini dikaitkan dengan ucapan atau pertuturan, maka sesuatu yang dituturnya boleh jadi tidak berdasarkan pertimbangan akal sehat atau logika yang benar, dan bisa jadi apa yang disampaikannya merupakan sangkaan- 
sangkaan saja yang diselimuti oleh hawa nafsunya.

Berdasarkan data Al-Quran, didapati ayat yang mempertegas prinsip ini, yaitu Q.S. An-Najm (53) : 23, Allah swt berfirman:

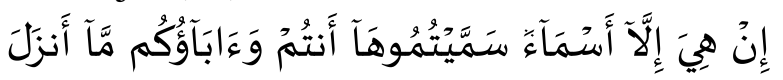

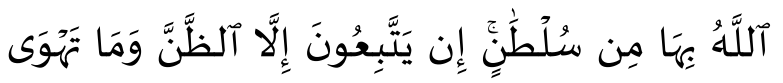

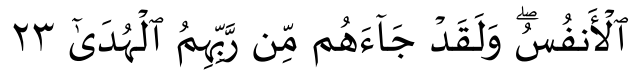

Itu tidak lain hanyalah nama-nama yang kamu dan nenek moyang kamu mengadaadakannya; Allah tidak menurunkan suatu keterangan apa pun untuk (menyembah) nya. mereka tidak lain hanyalah mengikuti dugaan, dan apa yang diingini oleh hawa nafsu mereka dan sesungguhnya telah datang petunjuk kepada mereka dari Tuhan mereka. (Q.S. An-Najm (53) : 23)

Ayat ini menjelaskan bahwa berhalaberhala yang dipertuhankan itu tidak lain hanyalah nama-nama yang tidak memiliki sifat ketuhanan. Apa yang dilakukan oleh para penyembah berhala itu, tidak lain hanyalah memaksakan diri dan mengikuti dugaan-dugaan tak mendasar, dan apa yang diingini oleh hawa nafsu mereka, padahal sungguh telah datang kepada mereka secara mudah dan tanpa bersusah payah mencarinya, dan bukan dari siapa-siapa, tetapi justru dari Tuhan Pemelihara mereka yang telah mendatangkan mereka petunjuk yang sempurna, kalau mendambakan petunjuk.

Quraish Shihab menjelaskan dalam Al-Mishbah (2009:190, jilid 13) bahwa kata "ظنّ " memiliki berbagai tingkat pembenaran hati, yaitu: Pertama, ia bisa berarti dugaan, yakni pembenaran yang belum mencapai tingkat kepastian, walau pembenarannya telah melebihi tingkat ragu. Kedua, ia juga digunakan dalam arti yakin kalau objeknya adalah persoalan metafisik, dan yang biasanya disertai dengan kata “أنّ " seperti firman Allah dalam surat Al-Haqqah (69) ayat 20:

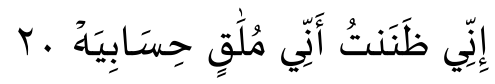

Sesungguhnya aku yakin, bahwa sesungguhnya aku akan menerima perhitungan terhadap diriku. (Q.S. AlHaqqah (69) : 20)

Ketiga, ia digunakan untuk menggambarkan kepercayaan yang bathil atau dugaan yang sama sekali sangat rapuh dasarnya, seperti dalam Q.S. Al-An'am (6) : 116:

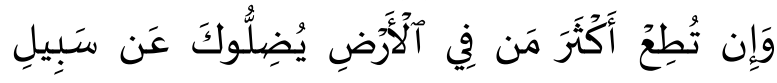

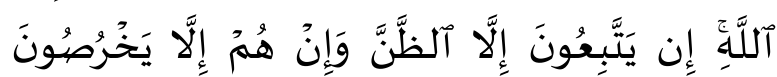

Dan jika kamu menuruti kebanyakan orang di muka bumi ini, niscaya mereka akan menyesatkanmu dari jalan Allah. mereka tidak lain hanyalah mengikuti persangkaan belaka, dan mereka tidak lain hanyalah berdusta (terhadap Allah). (Q.S. Al-An'am (6) : 116)

Hal yang dapat diambil kesimpulan dari tingkatan makna “ظّ di atas adalah hendaklah seseorang itu berhati-hati dalam bertutur menyangkut pembenaran atau penolakan satu hal yang masih bersifat belum pasti, sebab kalau tidak, maka ia seperti yang disebut dalam surat Al-An'am ayat 116, yaitu ia hanyalah membuat kebohongan.

Maka dari itu, dugaan ini tidak dapat dijadikan dasar dalam keyakinan keagamaan, sebagaimana Q.S. An-Najm (53) : 28, Allah swt berfirman:

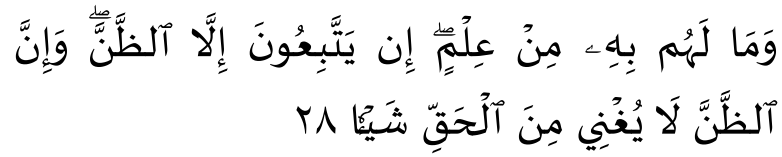

Dan mereka tidak mempunyai sesuatu pengetahuanpun tentang itu. mereka tidak lain hanyalah mengikuti persangkaan, dan sesungguhnya persangkaan itu tidak berfaedah sedikitpun terhadap kebenaran. (Q.S. An-Najm (53) : 28)

Ayat ini menjelaskan bahwa sesungguhnya kaum musyrikin Mekkah yang menyembah berhala itu, mereka benar-benar menamakan malaikat dan menyifati mereka dengan nama sifat perempuan dengan mengatakan bahwa mereka adalah anak perempuan Allah. Mereka mengatakan 
demikian padahal mereka tidak mempunyai suatu pengetahuan pun yang mendasari kepercayaan dan ucapan itu. Mereka tidak lain hanyalah mengikuti sekuat kemampuan dugaan mereka yang tidak berdasar kecuali hawa nafsu, sedang sesungguhnya dugaan tiada berfaedah sedikit pun menyangkut penetapan kebenaran yang bersifat pasti. Oleh karena itu, dugaan tidak dapat dijadikan dasar dalam keyakinan keagamaan.

Sebagai contoh, acapkali penutur mengucapkan tuduhan dalam tuturannya. Kalau ini dilakukan, tentu tuturannya itu menjadi tidak santun dan tidak beretika:

“...KPU selalu menyatakan kesiapannya dalam melaksanakan tugastugasnya, baik dalam mengelola tahapan pemilu maupun pengaturan calon perorangan. Kenyataannya janji KPU itu tidak pernah terbukti”. (Chaer, 2010:72)

Tuturan di atas tidak santun dan tidak beretika karena penutur menuduh mitra tutur atas dasar emosi dan kecurigaan belaka. Tuturannya "Kenyataannya janji KPU itu tidak pernah terbukti" menunjukkan praduga yang membabi buta, dan itu tampak dari penggunaan kata "tidak pernah". Sesuatu yang tidak logis kalau apa yang dikerjakan KPU semuanya tidak benar.

Jadi apa yang dituturkan dan cara menuturkan tidak sesuai dengan prinsip kesantunan yang dikemukakan Leech.

\section{SIMPULAN}

Pembahasan di atas adalah pengungkapan gambaran yang konkret bagaimana prinsip norma bertutur yang beretiket dan beretika dalam Al-Quran. Dalam konteks etiket, pada landasan "End" terungkap dua ( 2 ) prinsip: Pertama, Jangan bertutur sok tahu. Kedua, Jangan berdebat untuk membela yang tidak pantas untuk dibela. Pada landasan "Act Sequence" terungkap tiga (3) prinsip : Pertama, Jangan bertutur kata yang tidak berguna. Kedua, Jangan ikut terlibat dalam pertuturan yang bathil. Ketiga: Keharusan bertutur untuk saling nasehat-menasehati. Pada landasan "Key" terungkap tiga (3) prinsip : Pertama, Penggunaan kata "insya Allah" untuk kejadian esok atau akan datang. Kedua,
Penggunaan suara lunak dalam bertutur dan tidak membentak. Ketiga, Keseriusan dalam bertutur dan tidak senda gurau.

Dalam konteks etika, pada landasan "End" terungkap tiga ( 3 ) prinsip : Pertama, Jangan bertutur kata yang menyakiti mitra tutur. Kedua, jangan bertutur kata menyesatkan dan memperolok-olok, serta jangan memnaggil denga gelar yang buruk. Ketiga, Jangan menyombongkan diri atau membanggakan diri kepada mitra tutur.. Pada landasan "Act Sequence", terungkap tujuh ( 7 ) prinsip : Pertama, Bertutur kata sesuai hati nurani. Kedua: Jangan bertutur kata memfitnah. Ketiga, Jangan bertutur kata dusta. Keempat, Bertutur kata jujur untuk menegakkan keadilan. Kelima, Bertutur kata dengan amanah sesuai dengan yang diamanahi, tidak dilebih-lebihkan dan tidak dikurangi. Keenam: Jangan bertutur cacimaki dan mencela. Ketujuh, Jangan bertutur mempergunjingkan orang lain. Pada landasan "Key" terungkap dua ( 2 ) prinsip : Pertama: Bertutur kata dengan sikap rendah hati dan lemah lembut. Kedua, jangan bertutur kata berdasarkan hawa nafsu dan prasangka.

Pembahasan tersebut di atas membuktikan bahwa pada teks bahasa Al-Quran terdapat norma-norma bertutur yang beretiket dan beretika. Etiket bertutur dan etika bertutur adalah prinsip-prinsip bertutur yang harus diperhatikan dalam berkomunikasi. Prinsip bertutur ini adalah azas dan sendi, pendirian dan sikap, kaidah dan pedoman, yang bersifat universal bagi siapa saja dan dalam bahasa apa saja. Hal ini agar komunikasi dapat berlangsung dengan baik dan harmonis.

\section{DAFTAR PUSTAKA}

Al-Hasyimi, Abdul Mun'im.. Akhlak Rasul Menurut Bukhari dan Muslim. Edisi Terjemah. Penerjemah : Abdul Hayyie Al-Kattani dan Arif Chasanah Muna. Depok: Penerbit Gema Insani. 2009. 
Ali, Ahmad. Kitab Shahih Al-Bukhari dan Muslim. Cet. I. Jakarta: Alita Aksara Media. 2013.

Bertens, K. Etika. Edisi Revisi. Yogyakarta: Penerbit Kanisius. 2013.

Chaer, Abdul. Kesantunan Berbahasa. Jakarta: Rineka Cipta. 2010.

Endarmoko, Eko. Tesaurus Bahasa Indonesia. Cet. 1. Jakrta: Gramedia Pustaka Umum. 2006.

Hamka, Irfan. Ayah, Kisah Buya Hamka. Jakarta : Republika Penerbit. 2013.

Ibrahim, Abdul Qadir Asy-Syaikh. Duta Duta Islam Pada Masa Rasulullah. Penerjemah: Nurul Mukhlisin. Surabaya: Pustaka Yassir. 2013.
Raya, Ahmad Thib. Rasionalitas Bahasa Al-Quran, Upaya Menafsirkan Al-Quran dengan Pendekatan Kebahasaan. Jakarta: Fikra Publishing. 2006.

Shihab, M. Quraish. Tafsir Al-Mishbah: Pesan, Kesan dan Keserasian al-Quran. Edisi baru, cet. I. Jilid 1-15. Jakarta: Lentera Hati. 2009.

Sumarsono. Sosiolinguistik. Cetakan IX. Yogyakarta: Penerbit SABDA. 2013.

Zaenuddin, Mamat. Keindahan Ungkapan ILTIFAT Dalam Al-Quran. Bandung: Penerbit Nuansa Aulia. 2006. 